\title{
Invasion of Broom Snakeweed (Gutierrezia sarothrae) Following Disturbance: Evaluating Change in a State-and-Transition Model
}

\author{
Eric T. Thacker, ${ }^{1}$ Michael H. Ralphs, ${ }^{2}$ Christopher A. Call, ${ }^{3}$ Brock Benson, ${ }^{4}$ and Shane Green ${ }^{5}$
}

Authors are ${ }^{1}$ Graduate Student, Wildland Resources Department, Utah State University, Logan, UT 84322-5230, USA; ${ }^{2}$ Rangeland Scientist, USDA-ARSPoisonous Plant Research Lab, Logan, UT 84341, USA; ${ }^{3}$ Associate Professor, Wildland Resources Department, Utah State University, Logan, UT 843225230, USA; ${ }^{4}$ Range Specialist, USDA-NRCS, Ogden, UT 84401, USA; and ${ }^{5}$ State Range Conservationist, USDA-NRCS, Salt Lake City, UT 84105, USA.

\begin{abstract}
Broom snakeweed (Gutierrezia sarothrae [Pursh] Britt. \& Rusby) is an aggressive native invasive species that thrives after disturbance in semiarid rangelands of the western United States. A 5-yr (2002-2006) study was initiated following grazing and fire disturbances on an Upland Gravelly Loam ecological site in the sagebrush steppe of northern Utah, to evaluate broom snakeweed invasion in different plant communities. The study site originally had two plant communities: a sagebrush/ bunchgrass community that received alternate-year, fall cattle grazing, and was dominated by bluebunch wheatgrass (Elymus spicatus) and an open stand of Wyoming big sagebrush (Artemisia tridentata subsp. wyomingensis), and a sagebrush community that received continuous, annual, spring cattle grazing that removed the bunchgrasses, leaving a dense stand of Wyoming big sagebrush with an understory of Sandberg bluegrass (Poa secunda). Portions of these two plant communities were burned in a wildfire in 2001, removing the sagebrush, and creating two additional communities. The burned portion of the sagebrush/ bunchgrass community became a bluebunch wheatgrass-dominated community, and the burned portion of the sagebrush community became a snakeweed-dominated community. Foliar cover, aboveground biomass, and sagebrush and snakeweed densities were compared among the four communities. Mature snakeweed plants that existed in the sagebrush/bunchgrass community were eliminated in 2003, because of drought conditions. Snakeweed was eliminated in the bluebunch wheatgrass community by the wildfire in 2001 , and there was no reestablishment. Snakeweed density and cover remained constant in the sagebrush community. Snakeweed cover increased from $2 \%$ to $31 \%$ in the snakeweed community, despite the presence of Sandberg bluegrass. The data were used to evaluate and update the current Upland Gravelly Loam (Wyoming big sagebrush) ecological site description in the Great Salt Lake Major Land Resource Area and its state-and-transition model to reflect vegetation changes associated with snakeweed invasion.
\end{abstract}

\section{Resumen}

La escoba de rosita (Gutierrezia sarothrae (Pursh) Britt. \& Rusby) es una especie invasiva nativa agresiva la cual crece luego de la perturbación de pastizales semiáridos del oeste de los Estados Unidos. Un estudio de 5 años (2002-2006) fue iniciado posterior a las perturbaciones de pastoreo y fuego en un sitio ecológico de suelo limo- pedregoso en la estepa de artemisa en el norte de Utah, para evaluar la invasión de la escoba de rosita en diferentes comunidades de plantas. El sitio de estudio originalmente tuvo dos comunidades de plantas: una comunidad de artemisa/manojo de hierba en el que se alternó bianualmente el pastoreo otoñal de ganado, y fue dominado por la bluebunch wheatgrass (Elymus spicatus) y un rodal abierto de artemisa tridentata de Wyoming (Artemisia tridentata ssp. wyomingensis); y una comunidad de artemisa que recibió continuamente pastoreo de ganado, anual durante la primaveral el cual removió los manojo de hierbas, dejando un rodal espeso de artemisa tridentata de Wyoming con un sotobosque de hierba azul de Sandberg (Poa secunda). Porciones de estas dos comunidades de plantas fueron quemadas en un fuego natural en el 2001, removiendo la artemisa, y creando dos comunidades adicionales. La porción quemada de la comunidad de artemisa/manojo de hierba se convirtió en una comunidad dominante de bluebunch wheatgrass y la porción quemada de la comunidad de artemisa se convirtió en una comunidad dominante de escoba de rosita. La cobertura foliar, biomasa aérea, y las densidades de la artemisa y la escoba de rosita fueron comparadas entre las cuatro comunidades. Las plantas adultas de escoba de rosita que existían en la comunidad de artemisa y manojo de hierba fueron eliminadas en el 2003, debido a las condiciones de sequía. La escoba de rosita fue eliminada en la comunidad de bluebunch wheatgrass por fuego del 2001, y no hubo reestablecimiento. La densidad de la escoba de rosita y la cobertura permanecieron constantes en la comunidad de artemisa. La cobertura de la escoba de rosita aumentó de un 2\% a un 31\% en la comunidad de la escoba de rosita, a pesar de la presencia la hierba azul de Sandberg. Los datos fueron utilizados para evaluar y actualizar la actual descripción del sitio ecológico de suelo limoso pedregoso (artemisa de Wyoming) en la principal área de recursos naturales de Great Salt Lake Major, y su modelo de estado y transición para reflejar los cambios en la vegetación asociados a la invasión de la escoba de rosita.

Key Words: Artemisia tridentata subsp.wyomingensis, ecological site description, Elymus spicatus, fire, grazing, poisonous plant

Research was funded by the USDA-ARS Poisonous Plant Lab, Logan, UT 84341, USA. Correspondence: Michael Ralphs, USDA-ARS Poisonous Plant Lab, 1150E 1400N, Logan, UT 84341, USA. Email: Michael.Ralphs@ars.usda.gov

\section{INTRODUCTION}

Broom snakeweed (Gutierrezia sarothrae [Pursh] Britt. \& Rusby) is a low-growing, perennial suffrutescent shrub that 
occupies open plains, upland sites, and dry hillsides, and is adapted to a wide range of soils (McDaniel and Sosebee 1987). It is widely distributed throughout the Midwest and Intermountain regions, from northern Mexico to southern Canada. Snakeweed has become the dominant vegetation in some areas of the cold desert sagebrush steppe because of decades of heavy grazing, followed by catastrophic wildfire. When aboveaverage precipitation follows these disturbances, snakeweed seed can germinate, establish, and dominate the site for many years (McDaniel 1989; McDaniel et al. 2000; Ralphs and Sanders 2002). Snakeweed is a prolific seed producer, and seeds are widely dispersed by wind (Wood et al. 1997). Snakeweed is very competitive, displacing desirable grasses and forbs, resulting in significant reduction in forage production (Ueckert 1979; McDaniel et al. 1982). In addition, snakeweed contains toxic saponins, resins, and terpenes, which can cause abortions and other physiological problems in livestock (Dollahite and Anthony 1957).

State-and-transition models describe vegetation dynamics and management interactions associated with individual ecological sites (Briske et al. 2005), and reveal gaps in our knowledge (Bestelmeyer et al. 2003). Even though snakeweed is one of the most ubiquitous range weeds in the western Unites States, existing state-and-transition models do not account for its invasion and dominance in plant communities. The objectives of this article were 1) to describe the effects of past grazing practices and fire disturbances on an Upland Gravelly Loam (Wyoming big sagebrush) ecological site within the sagebrush steppe, and its subsequent ability to resist broom snakeweed invasion; and 2) to use the data to develop an additional phase to the state-and-transition model, describing the role of snakeweed and its impact on the resulting plant community.

\section{METHODS}

The study site was approximately $16.2 \mathrm{~km}$ west of Tremonton, Utah (lat $41^{\circ} 42^{\prime} 34^{\prime \prime} \mathrm{N}$, long $112^{\circ} 23^{\prime} 40^{\prime \prime} \mathrm{W}$, zone $12 \mathrm{~T}$ ), at 1500 m elevation. Soils were loamy skeletal frigid calcic Argixerols. The climate is characterized by warm dry summers, cold moist winters, and moist springs. The mean annual precipitation is $36.9 \mathrm{~cm}$. The study was conducted during a continuing 10-yr, regionwide drought. Annual precipitation was $20 \%$ below the long-term average in 2002, 2004, and 2006 water years, but was $43 \%$ below average in 2003, causing declines in grass cover and snakeweed. Precipitation in 2005 was $50 \%$ above average, with seasonal distribution much greater than average in fall, winter, and spring; yet there was essentially no summer precipitation.

The ecological site for the area was an Upland Gravelly Loam (Wyoming big sagebrush [Artemisia tridentata var. wyomingensis (Beetle \& Young) S. L. Welch]; USDA, NRCS 2007), which was originally dominated by Wyoming big sagebrush with an understory of bluebunch wheatgrass (Elymus spicatus [Pursh] Gould). The site was a north-facing slope divided by a fence running north and south and encompassed an area of about 1000 ha.

The east side of the fence historically received heavy seasonlong cattle grazing from the late 1800 s to 1947 . After 1947, the

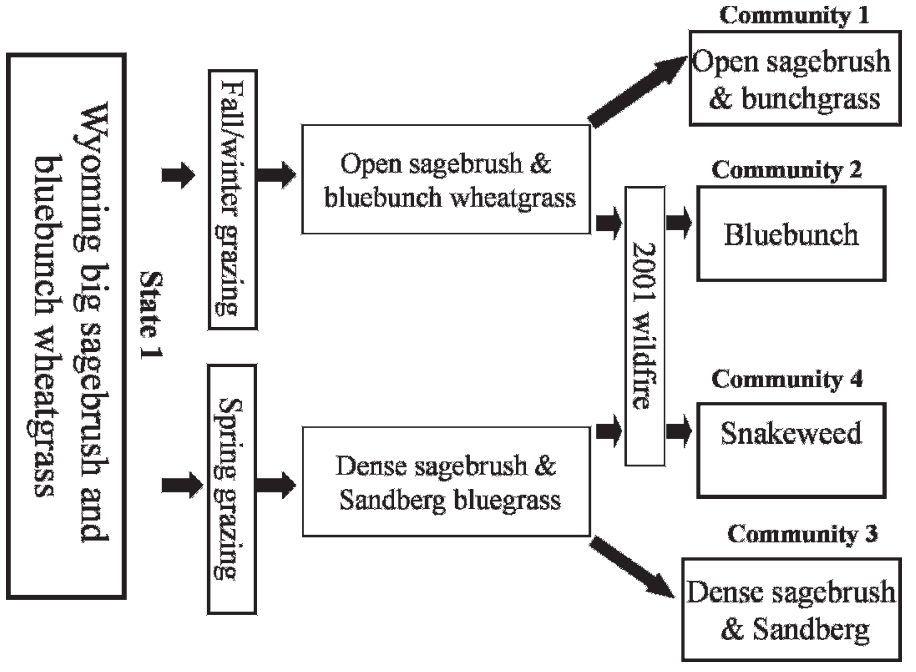

Figure 1. Wyoming big sagebrush/bluebunch wheatgrass plant community and the stressors of differential grazing and fire that created the original four plant communities.

valley bottom was dry farmed and fallowed every other year, which allowed the cattle to graze the slopes in fall and winter on alternate years. The west side of the fence received heavy season-long cattle grazing from the late 1800 s to approximately 1973, when cattle grazing was restricted to spring (MarchJune).

The entire study area burned in 1985 and sagebrush reestablished in varying degrees on both sides of the fence (Arthur Douglas, personal communication, 2006). In 2001, an August wildfire burned about 100 ha west of the fence and 400 ha east of the fence, creating four distinct plant communities. The first community (fall grazed-unburned) was dominated by scattered sagebrush and bluebunch wheatgrass (hereafter referred to as the sagebrush/bunchgrass community; Fig. 1). Broom snakeweed, rabbitbrush (Chrysothamnus nauseosus [Pall] Britt.), and various forbs (wild onion [Allium acuminatum Hook], yarrow [Achiliea millefolium L.], Lupinus spp. and Phlox spp.) were present but sparse. In the second community (fall grazed-burned), sagebrush and snakeweed were completely removed by the 2001 wildfire, and the site was dominated by bluebunch wheatgrass (hereafter referred to as the bluebunch wheatgrass community). The third community (spring grazed-unburned) was dominated by sagebrush (hereafter referred to as the sagebrush community), with Sandberg bluegrass (Poa secunda J. Presl.) the dominant grass, and snakeweed, clasping pepper weed (Lepidium perfoliatum L.), sunflower (Helianthus annuus L.), red stem filaree (Erodium cicutarium [L.] L'Her.) and cheatgrass (Bromus tectorum L.) present. Sagebrush was eliminated by the fire in the forth community (spring grazed-burned) leaving Sandberg bluegrass as the dominant species, but snakeweed increased over the study (hereafter referred to as the snakeweed community).

Four 10-m transects were placed within each plant community in a block design based on the following topographic characteristics: moderate slope $(<30 \%)$, steep slope $(>30 \%)$, flat, and rocky. Transects were placed in representative areas within each topographic class. Transects ran east and west and were oriented parallel to the slope. Foliar cover of the different species and bare ground were estimated by the line-intercept 
method. Densities of sagebrush, snakeweed, and rabbit brush plants were counted in a $1 \times 10 \mathrm{~m}$ belt transect, which was laid over the cover transect. Snakeweed plants were classified into three age classes: mature (more than five stems), juvenile (twofive stems), and seedling (single stem). Cover and density measures were taken annually in July from 2002 to 2006.

Aboveground biomass was clipped in each plant community in July 2005. A $0.25 \times 1 \mathrm{~m}$ quadrat was placed at the beginning and end of each transect. The plant material was clipped at ground level and divided into five classes: bunchgrasses (dominated by bluebunch wheatgrass), Sandberg bluegrass, forbs, snakeweed, and sagebrush. Sandberg bluegrass was put into its own category because it is low growing, shallow rooted, and matures early in the growing season (Daubenmire 1970). Biomass was dried at $45^{\circ} \mathrm{C}$ for $48 \mathrm{hr}$ and weighed to estimate aboveground biomass production for the different plant communities.

The cover and density data were analyzed in a $2 \times 2$ factorial design, using a repeated-measures mixed model analysis of variance (SAS 2003). Grazing regime and fire history were the fixed treatment effects, with two levels each. Transect location (block) was crossed with grazing and fire treatments, and was the random effect. Year was the repeated measure. Biomass production was analyzed in a similar model, excluding the year effect.

\section{RESULTS}

Cover of snakeweed, bunchgrasses, and sagebrush changed in the plant communities over the 5 -yr study $(P<0.05)$, and the three-way interaction of graze-by-fire-by-year was significant for all cover classes $(P<0.05)$. The study started in 2002 with four very distinct plant communities (Fig. 1). The sagebrush/ bunchgrass community consisted of an open stand of Wyoming big sagebrush $(7 \% \pm 1.2 \%$ cover $)$ and perennial bunchgrasses $(30 \% \pm 4.3 \%$ cover $)$ dominated by bluebunch wheatgrass (Fig. 2). Snakeweed was present in the community ( $3 \% \pm 1.4 \%$ cover) at the beginning, but died out following the 2003 drought. Sagebrush density remained constant over the study $\left(0.2\right.$ plants $\left.\cdot \mathrm{m}^{-2}\right)$.

The bluebunch wheatgrass community was dominated exclusively by bunchgrasses $(34 \% \pm 6 \%$ cover $)$, which increased to $53 \% \pm 2.9 \%$ cover in 2005 (Fig. 2). Sagebrush and snakeweed were removed by the 2001 fire and did not return.

The sagebrush community was dominated by Wyoming sagebrush $(13 \% \pm 2 \%$ cover $)$ with a depleted bunchgrass understory $(1 \% \pm 0.3 \%)$. Sandberg bluegrass was the major understory species $(15 \% \pm 0.5 \%$ cover $)$. Density of mature snakeweed plants remained constant $\left(1.5\right.$ plants $\left.\cdot \mathrm{m}^{-2}\right)$, and snakeweed cover remained stable $(4 \% \pm 1.2 \%)$ through the study. Density of sagebrush remained constant (2.5 plants . $\mathrm{m}^{-2}$ ), but its cover increased from $13 \%$ to $28 \%$ as the plants grew in size (Fig. 2).

Sandberg bluegrass was the dominant grass in the snakeweed community at the beginning of the study $(13 \% \pm 1.4 \%$ cover $)$, and it remained relatively stable throughout the study (data not shown). Snakeweed established quickly following the fire $(2 \% \pm 0.6 \%$ cover in 2002) and greatly increased to
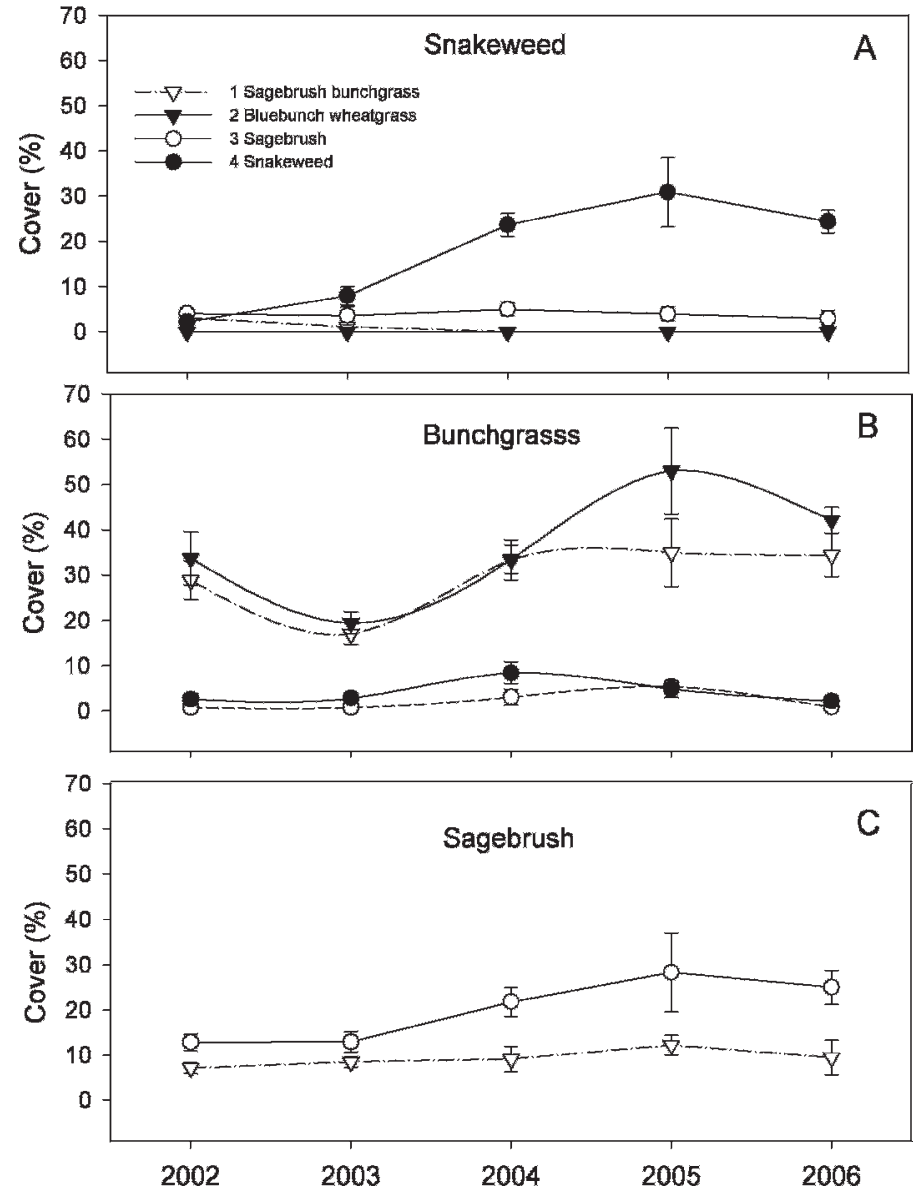

Figure 2. Mean cover (with SE bars) over the duration of the study for A, broom snakeweed; B, bunchgrasses, and C, sagebrush in the four plant communities.

$31 \% \pm 7.7 \%$ cover in 2005 (Fig. 2). Snakeweed age class density progressed from $26.6 \pm 5.3$ seedlings $\cdot \mathrm{m}^{-2}$ in 2002 , to $12.2 \pm 1.61$ juvenile plants $\cdot \mathrm{m}^{-2}$ in 2003 , ending up with $12.0 \pm 1.3$ mature plants $\cdot \mathrm{m}^{-2}$ in 2004 and 2005. Snakeweed established and persisted in this plant community, even though the total mean precipitation was only $43 \%$ of the long-term average in 2003. We expected germination of snakeweed seedlings in response to the large amount of winter and spring precipitation in 2005, but there was no summer precipitation, which apparently prevented the seedlings from establishing.

Total aboveground biomass production for the sagebrush/ bunchgrass, and bluebunch wheatgrass communities was significantly different from the sagebrush and snakeweed communities $(P \leq 0.0001$; Table 1$)$. The sagebrush/bunchgrass and bluebunch wheatgrass communities had an average biomass production of $2430 \pm 123 \mathrm{~kg} \cdot \mathrm{ha}^{-1}$, of which $78 \%$ was bunchgrasses, whereas the sagebrush and snakeweed communities 3 and 4 had an average biomass production of $1177 \pm 132 \mathrm{~kg} \cdot \mathrm{ha}^{-1}$, of which sagebrush and snakeweed comprised $63 \%$ of the total biomass, respectively. Snakeweed aboveground biomass production was significantly higher in the snakeweed community $\left(833 \pm 148.2 \mathrm{~kg} \cdot \mathrm{ha}^{-1}, P=0.022\right)$ compared to the other communities, and the sagebrush community had the greatest sagebrush biomass $(457 \pm 224.2$ $\left.\mathrm{kg} \cdot \mathrm{ha}^{-1}\right)$. 
Table 1. Aboveground biomass for each state and plant community in 2005 . $^{1}$

\begin{tabular}{|c|c|c|c|c|c|c|c|c|c|c|}
\hline \multirow[b]{2}{*}{ State } & \multirow[b]{2}{*}{ Dominant vegetation } & \multicolumn{2}{|c|}{ Grasses } & \multicolumn{2}{|c|}{ Forbs } & \multicolumn{2}{|c|}{ Sagebrush } & \multicolumn{2}{|c|}{ Snakeweed } & \multirow[b]{2}{*}{ Total } \\
\hline & & $\mathrm{kg} \cdot \mathrm{ha}^{-1}$ & $\%$ & $\mathrm{~kg} \cdot \mathrm{ha}^{-1}$ & $\%$ & $\mathrm{~kg} \cdot \mathrm{ha}^{-1}$ & $\%$ & $\mathrm{~kg} \cdot \mathrm{ha}^{-1}$ & $\%$ & \\
\hline \multicolumn{11}{|c|}{ Reference state $\mathrm{ESD}^{2}$} \\
\hline 1.2 & Sagebrush & - & $15-25$ & - & $20-35$ & - & $45-80$ & - & - & - \\
\hline 1.3 & Perennial grass & - & $60-90$ & - & $15-25$ & - & $5-20$ & - & - & - \\
\hline 2.3 & Bluebunch wheatgrass & $1929 a$ & 79 & 63 & 3 & 0 & 0 & $0 \mathrm{c}$ & 0 & $2452 \mathrm{a}$ \\
\hline \multicolumn{11}{|c|}{ Sage/snakeweed state ${ }^{4}$} \\
\hline 4.1 & Sagebrush & $100 \mathrm{~b}$ & 9 & 18 & 2 & 456 & 42 & $195 \mathrm{~b}$ & 18 & $1077 \mathrm{~b}$ \\
\hline 4.2 & Snakeweed & $195 \mathrm{~b}$ & 15 & 33 & 3 & 0 & 0 & $834 \mathrm{a}$ & 65 & $1278 b$ \\
\hline
\end{tabular}

${ }^{1}$ Letters indicate significant differences $(P<0.05)$.

${ }^{2}$ Data taken from the ecological site description (ESD) reference state.

${ }^{3}$ Data collected from our sagebrush/bunchgrass and bluebunch wheatgrass plant communities 1 and 2 that correspond to States 2.2 and 2.3 in ESD state-and-transition model (Fig. 3 ).

${ }^{4}$ Data collected from our sagebrush and snakeweed communities 3 and 4 that corresponds to States 4.1 and 4.2 , in the ESD state-and-transition model (Fig. 3).

\section{DISCUSSION}

\section{Plant Community Change}

Snakeweed was eliminated in the sagebrush/bunchgrass plant community. Competition from bunchgrasses and sagebrush for the limited amount of soil moisture in 2003 drought year likely caused the demise of snakeweed in this community. Snakeweed can resist moderate drought, but death rapidly occurs when soil water potential drops below - 7.5 MPa (Wan et al. 1993a). On the other hand, bluebunch wheatgrass is one of the most drought-tolerant species in the sagebrush steppe (USDA Forest Service 1937). It has a dense root mass within $0.5 \mathrm{~m}$ of the soil surface, but can extract soil moisture below $1 \mathrm{~m}$ (Cline et al. 1977). Wan et al. (1993b) compared water extraction by snakeweed and sand dropseed (Sporobolus cryptandrus), a drought-resistant grass in the short-grass prairie. The dense root mass of sand dropseed extracted more water from the top $30 \mathrm{~cm}$ of the soil profile, but the deeper roots of snakeweed were able to penetrate and extract stored water beyond $60 \mathrm{~cm}$. Most of snakeweed roots are within the top $80 \mathrm{~cm}$ of the soil surface (Lee and Lauenroth 1994).

There was no reinvasion of snakeweed in the bluebunch wheatgrass community following the wildfire. We speculate the abundance of perennial bunchgrasses in the sagebrush/bluebunch wheatgrass plant communities suppressed reestablishment of snakeweed. Thacker (2005) reported interspecific interference from cool-season grasses caused high mortality and suppressed growth of snakeweed seedlings.

Snakeweed density and cover remained unchanged in the sagebrush community during the study period. Again we speculate the dominance of sagebrush prevented snakeweed expansion. The root system of Wyoming big sagebrush is deep and well developed, with many lateral roots that extend $1.2 \mathrm{~m}$ laterally, and tap roots that penetrated as deep as $1.8 \mathrm{~m}$ (Sturges 1977). Yet, $35 \%$ of the roots are in the upper $30 \mathrm{~cm}$, indicating significant competition for soil moisture throughout the soil profile.

The snakeweed plant community was the only plant community to have successful snakeweed recruitment and expansion. There was neither abundant bunchgrasses nor dense sagebrush; thus the only species left to compete with invading snakeweed was Sandberg bluegrass. Sandberg bluegrass is an early emerging, shallow-rooted species that uses soil water from the upper soil profile early in the growing season (Daubenmire 1970). Sandberg bluegrass apparently is not able to keep snakeweed from invading a degraded site.

\section{State-and-Transition Model}

NRCS developed a state-and-transition model for the Upland Gravelly Loam (Wyoming big sagebrush) ecological site (USDA, NRCS 2007). This model did not account for the dominance of broom snakeweed in some of the degraded states on this site. We used the data from our study to expand this state-and-transition model and describe a new phase dominated by snakeweed in the Wyoming big sagebrush State 4 (Fig. 3).

Our sagebrush/bunchgrass and bluebunch wheatgrass communities were similar to the current potential State 2.2 (Wyoming big sagebrush/perennial grasses) and 2.3 (perennial grasses) in the ecological site description (ESD; Fig. 3). Fire removed sagebrush in our sagebrush/bunchgrass community, and shifted it along the community pathway (2.2a) to the bluebunch wheatgrass community (ESD 2.3). In time, sagebrush will gradually increase and shift back along the pathway (2.3a) to a plant community similar to the Wyoming big sagebrush/perennial grass State 2.1.

Decades of spring grazing led to dense sagebrush and a depleted understory void of perennial bunchgrasses in our sagebrush community. This community transitioned across a threshold (T2b) to a new state with a dense overstory of sagebrush and understory of Sandberg bluegrass (Wyoming big sagebrush, State 4.1). This situation is not likely to be reversed with the removal of grazing for any practical management time frame. West et al. (1984) showed that after $13 \mathrm{yr}$ of grazing exclusion, the depleted understory was not able to recover, and sagebrush cover continued to increase.

Our snakeweed community was further degraded along pathway (4.1a) by removal of the dominant sagebrush in the 


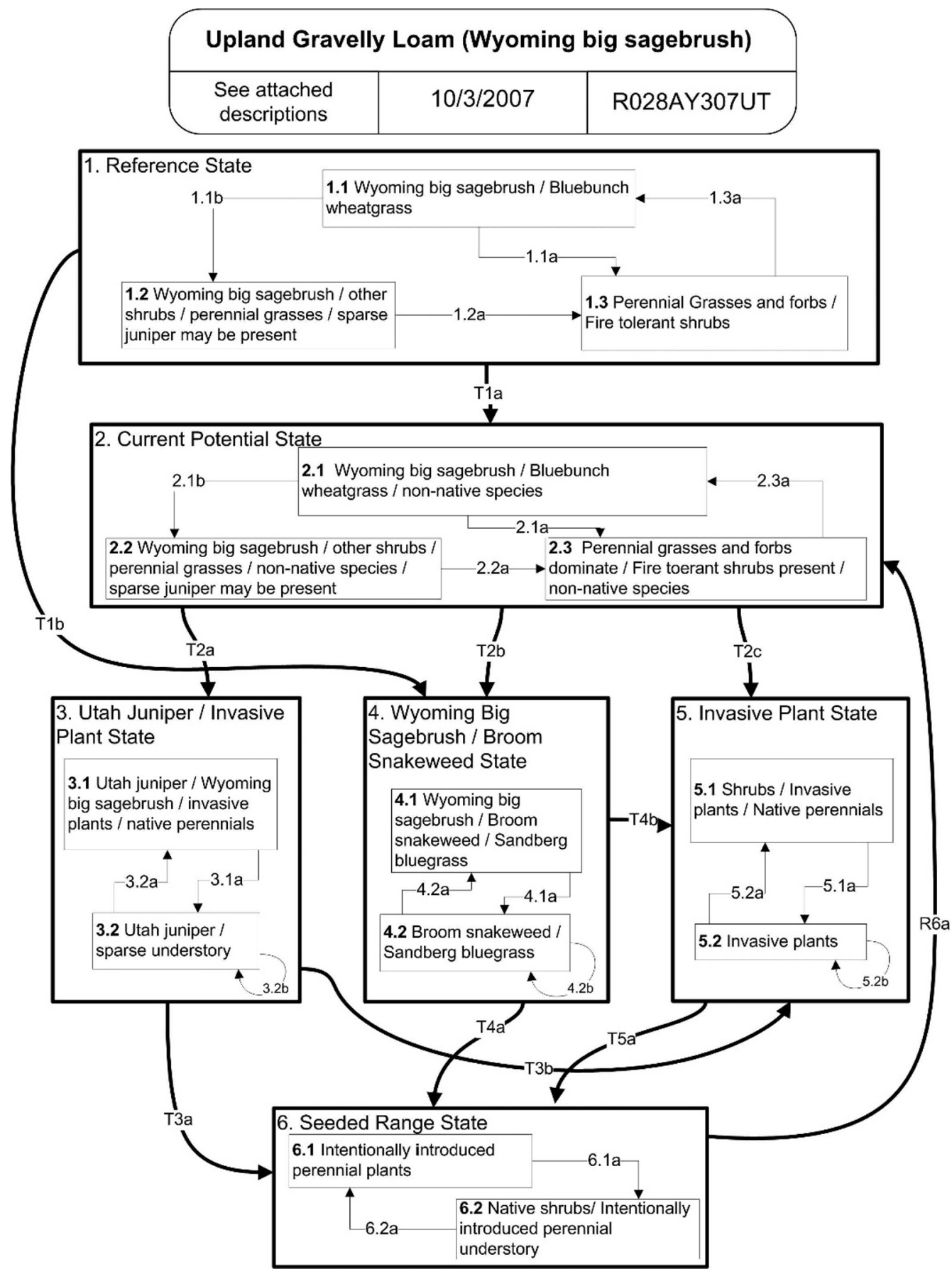

Figure 3. NRCS state-and-transition model for Upland Gravelly Loam (Wyoming sagebrush) ecological site. Bold lines represent ecological states; grey lines within the states represent the different plant communities. The arrows inside the box represent pathways between plant communities, which are reversible, whereas the arrows outside of the boxes represent transitions to new states. Letters following pathways or transitions are stressors or factors driving change.

2001 wildfire, creating the new broom snakeweed/Sandberg bluegrass phase (ESD 4.2). Snakeweed germinated, established, and dominated the site within $3 \mathrm{yr}$. It could be argued that snakeweed is a short-lived perennial, and in time, will die out and allow the community to shift back along pathway (4.2a) to a more desirable community or state. However, when snakeweed was removed from a similar site, cheatgrass increased dramatically (Thacker 2005). This suggests that if disturbance (i.e., fire, drought, or insect) removed the snakeweed from phase 4.2 before sagebrush reestablished, another threshold (T4b) would be crossed to a cheatgrassdominated state (State 5). West and Hassan (1985) suggest that even though cheatgrass is a minor component of a plant community, it can quickly assume dominance following a wildfire in a sagebrush/bunchgrass site. In the case of the snakeweed community, it will require accelerating practices (brush control and grass seeding to transition (T5a) to a more productive and stable state (State 6). 


\section{MANAGEMENT IMPLICATIONS}

A new phase was added to the state-and-transition model for the Upland Gravelly Loam (Wyoming big sagebrush) ecological site. The broom snakeweed/Sandberg bluegrass phase was added to the Wyoming big sagebrush state (4.2). This change may be applicable to other sagebrush sites within the Great Salt Lake Major Land Resource Area, which comprises $95300 \mathrm{~km}^{2}$ of western Utah, eastern Nevada, and southeastern Idaho. This project represents the needed collaborations between the research community and management agencies to improve the utility of state-and-transition models, as suggested by Bestelmeyer et al. (2003). This research identified two mechanisms that can lead to snakeweed invasion. Heavy spring grazing almost eliminated the bunchgrass component of the plant community, transitioning over a threshold to a dense Wyoming sagebrush state. Fire removed the sagebrush allowing snakeweed to increase and dominate the state. Subsequent fires will remove snakeweed and the site will likely transition over another threshold to a cheatgrass community. The research also suggests that if robust perennial bunchgrasses can be maintained in the community, they will resist snakeweed invasion or expansion, recover from disturbances, and produce more forage for wildlife and livestock. This state-and-transition model can be used by managers to predict snakeweed's response in the sagebrush-steppe community on this site.

\section{LITERATURE CITED}

Bestelmeyer, B. T., J. R. Brown, K. M. Havstad, R. Alexander, G. Chavez, and J. E. HerRICK. 2003. Development and use of the state-and-transition models for rangelands. Journal of Range Management 56:114-126.

BRiske, D. D., S. D. Fuhlendorf, And F. E. Smeins. 2005. State-and-transition models, thresholds, and rangeland health: a synthesis of ecological concepts and perspectives. Rangeland Ecology and Management 58:1-10.

Cline, J. F., D. W. Uresk, and W. H. Richard. 1977. Comparison of soil water used by a sagebrush-bunchgrass and a cheatgrass community. Journal of Range Management 30:199-201.

Daubenmire, R. 1970. Steppe vegetation of Washington. Washington Agriculture Experiment Station Technical Bulletin $62.131 \mathrm{p}$.

Dollahite, J. W., and W. V. Anthony. 1957. Poisoning of cattle with Gutierrizia microphala, a perennial broomweed. Journal of the American Veterinary Medical Association 130:525-530.
Lee, C. A., and W. K. Lauenroth. 1994. Spatial distributions of grass and shrub root systems in the shortgrass steppe. American Midland Naturalist 132:117123.

McDaniel, K. C. 1989. Snakeweed populations in New Mexico, 1979-1989. In: E. W. Huddleston and R. E. Pieper [EDS.]. Snakeweed: problems and perspectives. Las Cruces, NM, USA: New Mexico State University Agricultural Experiment Station Bulletin 751. p. 13-25.

McDaniel, K. C., C. R. Hart, and D. B. Carroll. 2000. Broom snakeweed establishment following fire and herbicide treatments. Journal of Range Management 53:239-245.

McDaniel, K. C., R. D. Pieper, and G. E. Donnart. 1982. Grass response following thinning of broom snakeweed. Journal of Range Management 35:219-222.

McDaniel, K. C., and R. E. Sosebee. 1987. Taxonomy, ecology, and poisonous properties associated with perennial snakeweeds. In: L. F. James, M. H. Ralphs, and D. B. Nielson [EDS.]. The ecology and economic impact of poisonous plants on livestock production. Boulder, C0, USA: Westview Press. p. 43-56.

Ralphs, M. H., and K. D. Sanders. 2002. Population cycles of broom snakeweed in the Colorado Plateau and Snake River Plains. Journal of Range Management $55: 406-411$

SAS. 2003. Statistical analysis system 9.1. Cary, NC, USA: SAS Institute Inc.

StuRgeS, D. L. 1977. Soil water withdrawal and root characteristics of big sagebrush. American Midland Naturalist 98:257-274.

THACKER, E. T. 2005. Ecologically based management of snakeweed-infested sagebrush steppe communities in the Great Basin [thesis]. Logan, UT, USA Utah State University. $100 \mathrm{p}$.

UECKERT, D. N. 1979. Broom snakeweed: effect on shortgrass forage production and soil water depletion. Journal of Range Management 32:216-220.

USDA Forest Service. 1937. Range plant hand book. Washington, DC, USA: U.S. Government Printing Office. p. G6.

USDA, NRCS. 2007. Ecological site description for: Upland Gravelly Loam (Wyoming big sagebrush). Available at: ftp://ftpfc.sc.egov.usda.gov/UT/ Range/D28AY/28AY307UT.pdf. Accessed 17 November 2007.

Wan, C., R. E. Sosebee, and B. L. McMichael. 1993a. Broom snakeweed responses to drought: II. Root growth, carbon allocation and mortality. Journal of Range Management 46:360-363.

Wan, C., R. E. Sosebee, and B. L. McMichael. 1993b. Soil water extraction and photosynthesis in Gutierrezia sarothrae and Sporobolus cyrptandrus. Journal of Range Management 46:425-430.

West, N. E., and M. A. Hassan. 1985. Recovery of sagebrush-grass vegetation following wildfire. Journal of Range Management 38:131-134.

West, N. E., F. D. Provenza, P. S. Johnson, and M. K. Owens. 1984. Vegetation change after 13 years of livestock grazing exclusion on sagebrush semidesert in west central Utah. Journal of Range Management 37:262-264.

Wood, B. L., K. C. McDaniel, and D. Classon. 1997. Broom snakeweed (Gutierrezia sarothrae) dispersal, viability, and germination. Weed Science 45:77-84. 